\title{
Report recommends ban of US GM maize in Mexico
}

A recent report on the possible effects of GM maize from the US on maize and other native plants in neighboring Mexico points to problematic regulatory and cultural gaps between the two countries, despite a recent move by Mexico to regulate GM crops. Moreover, recommendations in the report, which include maintaining a de facto moratorium in Mexico on GM corn, could prove ominous for other countries where GM crops could outcross to native plant relatives. Although this report has no direct bearing, its spirit runs counter to longstanding US interests in that country's trade case against Europe over GM crops, which was brought before the World Trade Organization in May 2003.

Nearly three years ago, a coalition of Mexican farmers, environmentalists and representatives from indigenous communities asked for a study of the effects of GM corn on native maize and related plants such as teosinte. This petition went to the Commission for Environmental Cooperation (CEC) - an organization that Canada, Mexico and the US established under the North American Agreement on Environmental Cooperation, itself an offshoot of the North American Free Trade Agreement (NAFTA).

The ensuing CEC advisory report, Maize and Biodiversity: The Effects of Transgenic Maize in Mexico: Key Findings and Recommendations, was made public in November. The report calls for enforcing the current de facto moratorium on commercial planting of GM corn in Mexico and for milling corn that's imported for feed to keep it from being planted, as acceptable ways for preserving the integrity of the wild races of corn and teosinte, which are deemed of special importance by the indigenous peoples and also by many clerics in Mexico. Although the CEC advisory group was careful to say that GM corn is safe and useful in the US and is "probably even safe in Mexico," explains Julian Kinderlerer, Professor of Environmental Law at the University of Sheffield in the UK and a member of the CEC advisory group, "the report is also saying 'respect peoples' culture... and there's a need to take issues other than the purely scientific into account."”

Other recommendations in the report include the need to find better ways of conserving Mexican maize and teosinte races and to better coordinate biotechnology regulatory policies among Mexican, Canadian and US governments. Among its 16 formal recommendations, which are purely advisory, the report calls for further research into and use of better methods to monitor gene flow and potential health effects of GM corn as well as ways to mitigate gene flow, should it occur.

The US government formulated instant and sweeping criticisms to the report whereas Mexican and Canadian officials only objected to parts of it. In a pointed, jointly issued statement, officials of the US Environmental Protection Agency and the Office of the US Trade Representative called the CEC report "fundamentally flawed and unscientific" and claimed that many of its recommendations are untenable for being "based solely on sociocultural considerations.” Moreover, according to the joint statement, "Implementing many of the report's recommendations would cause economic harm to farmers and consumers in all NAFTA countries and restrict international trade."

The emphatic response of US officials surprised Don Doering of Winrock International in Arlington, Virginia, who was part of the advisory group that wrote the CEC report. "It's kind of amazing the US is so reliant on its regulatory system [for biotechnology] but shows such disregard for regulatory systems

\section{Box 1 Regulatory wrangle over another gene flow case}

The US biotech regulatory scene is far from settled, and federal officials continue to amend and augment the federal biotechnology regulatory system while using it for enforcement purposes, insiders point out. Since last August, for example, officials in the US Department of Agriculture (USDA) Biotech Regulatory Service have been investigating an accidental release from a test plot in Oregon of seeds of a GM grass, specifically, Roundup Ready creeping bentgrass. Although its developers, the Scotts Company of Marysville, Ohio, and Monsanto of St. Louis, Missouri, are asking USDA to deregulate the product, critics say that this species spreads aggressively and is likely to transmit its herbicide-resistant transgenes to wild and weedy relatives. Early last December, the agency closed the docket for public comments on its planned environmental impact statement reviewing the companies' request.

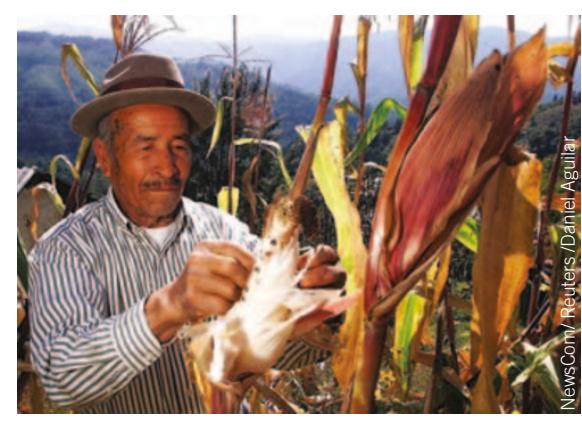

Farmers in Mexico should carry on using traditional corn, instead of its genetically modified version, for socio-cultural reasons, a new report recommends.

in other countries" (see Box 1). One important theme in the CEC report is to allow the Mexican government time to establish its own regulatory regime for evaluating the local impact of GM corn. Incidentally, soon after the report was published, Mexico voted a new law, on December 14, that regulates GM crops. Opponents complain that the law caters for the interest of big business without protecting the country's biodiversity.

The US reaction reflects a broader strategy to discredit criticisms of GM that interfere with exports of such agbiotech products, including those meant for European markets, according to Kinderlerer. "Part of the reason the US is scoffing at this report is to protect its markets and because of concern that other countries will put up barriers to US (agbiotech) products," he says. If accepted even informally as establishing a precedent, the CEC report could prove damaging to the challenge before the World Trade Organization that the United States brought against Europe regarding its alleged trade barriers to GM crops and foods.

The CEC report focuses on traits in a GM crop from one country potentially contaminating native and related species of that crop in a nearby developing country-a situation that need not be limited to corn or to the US and Mexico. Thus, for example, GM plantings in South America are increasing, questions about GM imports to African nations persist and China seems poised to step up its GMcrop-related activities, according to Doering. In this context, he says, "Lots of countries look more like Mexico than they look like the US...My suspicion is that the CEC report will have a long life, and certainly where Mexican GM crops are concerned."

Jeffrey L. Fox, Washington 